Students' perceptions of religion and science, and how they relate: The effects of a classroom intervention

Alexis Stones, Jo Pearce, Michael J. Reiss, Tamjid Mujtaba

Corresponding/1st Author:

Alexis Stones

UCL Institute of Education, University College London

20 Bedford Way,

London,

WC1H 0AL.

United Kingdom.

+44 (0)2076126707

a.stones@ucl.ac.uk

$2^{\text {nd }}$ Author:

Dr Jo Pearce

UCL Institute of Education, University College London.

$3^{\text {rd }}$ Author:

Professor Michael J. Reiss

UCL Institute of Education, University College London.

$4^{\text {th }}$ Author:

Dr Tamjid Mujtaba

UCL Institute of Education, University College London.

None of the authors have interests to disclose.

Notes on Contributors

All four authors work at UCL Institute of Education, University College London. Alexis Stones is a Senior Teaching Fellow, Jo Pearce is a Principal Teaching Fellow, Michael J. Reiss is Professor of Science Education, Tamjid Mujtaba is a Senior Research Officer. Correspondence concerning this article should be addressed to the corresponding author: Alexis Stones, UCL Institute of Education, University College London, 20 Bedford Way, London WC1H 0AL, UK. E-mail: a.stones@ucl.ac.uk. 


\begin{abstract}
In England, both Religious Education (RE) and science are mandatory parts of the school curriculum throughout the 5-16 age range. Nevertheless, there remain concerns that, as in many countries, students do not have a good understanding about the scope of each subject nor about how the two subjects relate. This article reports on a study that involved an intervention of six lessons in RE and six in science that were intended to help 13-15 year-old students develop a better appreciation about the relationship between science and religion and a less reductionist understanding of biology. Our focus here is on the understandings that students have about the relationship between science and religion. The intervention was successful in improving the understandings of almost half of the students interviewed, but in these interviews we still found many instances where students showed misunderstandings of the nature of both religious and scientific knowledge. We argue that RE needs to attend to questions to do with the nature of knowledge if students are to develop better understandings of the scope of religions and how they arrive at their knowledge claims.
\end{abstract}

\title{
Keywords
}

Science and religion, nature of science, Religious Education, knowledge 


\section{Students' perceptions of religion and science, and how they relate: The effects of a classroom intervention}

\section{Introduction}

We know rather little about how school teaching about science and, in countries where this is possible, religion affect how students understand the scope of these disciplines and the ways in which they build knowledge. In the research we report here, we looked at student perceptions of religion and science, and the relationship(s) between them. Our study involved an intervention in England in Religious Education (RE) and science lessons (Pearce et al. 2019). Issues of philosophy, including ethics, were raised in science. The RE lessons highlighted the question of the relationship(s) between religion and science. We conducted student interviews pre- and post-intervention to determine students' understandings and to see whether these had changed as a result of the lessons. Our analysis demonstrates the value of enabling students to explore and be taught how religion and science arrive at their conclusions. We are particularly interested in the contribution that RE can make to this.

\section{The nature of science}

The phrase 'the nature of science' is used as a shorthand for something like 'how science is done and what sorts of things scientists work on'. It therefore contains two elements: the practice of doing science and the knowledge that results (Reiss 2008a).

It is difficult to come up with a definitive answer to the question 'What do scientists study?'. Certain things clearly fall under the domain of science - forces, the structure of DNA and the operation of the endocrine system, to give three examples. However, what about the origin of the universe, the behaviour of people in society, decisions about whether we should build nuclear power plants or go for wind power, the appreciation of music and the nature of love, for example? Do these come within the domain of science? Although a small proportion of people, including a few prominent scientists, would not only argue 'yes' but maintain that all meaningful questions fall within the domain of science (or mathematics), most people hold that science is but one form of knowledge and that other forms of knowledge complement science.

This way of thinking means that the origin of the universe is also a philosophical or religious question - or simply unknowable; understanding the behaviour of people in society requires knowledge of the social sciences (including psychology and sociology) rather than only of the natural sciences; whether we should go for nuclear or wind power is partly a scientific issue but also requires an understanding of economics, risk and politics; the appreciation of music and the nature of love, while clearly having something to do with our perceptual apparatuses and our evolutionary history, cannot entirely be reduced to science.

While historians tell us that what scientists study changes over time, there are reasonable consistencies: 
- Science is concerned with the natural world and with certain elements of the manufactured world - so that, for example, the laws of gravity apply as much to artificial satellites as they do to planets and stars.

- Science is concerned with how things are rather than with how they should be. So, there is a science of gunpowder and in vitro fertilisation without science telling us whether warfare and test-tube births are good or bad.

It is difficult to come up with a clear-cut answer to the question 'How is science done?'. Robert Merton characterised science as open-minded, universalist, disinterested and communal (Merton 1973). For Merton, science is a group activity: even though certain scientists work on their own, all scientists contribute to a single body of knowledge accepted by the community of scientists. Of course, individual scientists are passionate about their work and often slow to accept that their cherished ideas are wrong. But science itself is not persuaded by such partiality. For this reason, scientists are well advised to retain 'open mindedness', always being prepared to change their views in the light of new evidence or better explanatory theories, and science itself advances over time.

Karl Popper emphasised the falsifiability of scientific theories (Popper 1934/1972): unless you can imagine collecting data that would allow you to refute a theory, the theory isn't scientific. The same applies to scientific hypotheses. So, iconically, the hypothesis 'All swans are white' is scientific because we can imagine finding a bird that is manifestly a swan (in terms of its anatomy and behaviour) but is not white. Indeed, this is precisely what happened when early explorers returned from Australia with tales of black swans.

Popper's ideas easily give rise to a view of science in which knowledge accumulates over time as new theories are proposed and new data collected to discriminate between conflicting theories. Much school experimentation in science is Popperian in essence: we establish that plants take in carbon dioxide and use it in photosynthesis. We therefore hypothesize that if we remove carbon dioxide from the air around a terrestrial plant (for instance, by using potassium hydroxide to absorb carbon dioxide), the plant will stop growing even if other environmental conditions (temperature, light, water availability) are ideal for photosynthesis. We test the hypothesis and it is confirmed. Until some new evidence causes it to be falsified, we accept it.

Thomas Kuhn made a number of seminal contributions to the philosophy of science but he is most remembered nowadays for his argument that while the Popperian account of science holds well during periods of normal science when a single paradigm holds sway, such as the Ptolemaic model of the structure of the solar system (in which the Earth is at the centre) or the Newtonian understanding of motion and gravity, it breaks down when a scientific crisis occurs (Kuhn 1970). At the time of such a crisis, a scientific revolution happens during which a new paradigm, such as the Copernican model of the structure of the solar system or Einstein's theory of relativity, begins to replace (initially to co-exist with) the previously accepted paradigm. The central point is that the change of allegiance from scientists believing (and our use of this word is intentional) in one paradigm to their believing in another cannot, Kuhn argues, be fully explained by the Popperian account of falsifiability. Kuhn likens the switch from one paradigm to another to a gestalt switch (when we suddenly see something in a new way) or even a religious conversion.

A development of Kuhn's work was provided by Lakatos (1978) who argued that scientists work within research programmes. A research programme consists of a set of core beliefs

Stones, A., Pearce, J., Reiss, M. J. \& Mujtaba, T. (2020) Students' perceptions of religion and science, and how they relate: The effects of a classroom intervention. Religious Education. DOI: $10.1080 / 01416200.2019 .1635434$. 
surrounded by layers of less central beliefs. Scientists are willing to accept changes to these more peripheral beliefs so long as the core beliefs can be defended. So, in biology, we might see in ecology a core belief in the notion that all heterotrophs depend on autotrophs for nutrition. At one point, it was thought that all heterotrophs depend on photosynthesis for nutrition. Now we know (chemosynthesis) that this is not always the case. The core belief (all heterotrophs depend on autotrophs for nutrition) remains unchanged but the less central belief (all heterotrophs depend on photosynthesis for nutrition) is discarded.

\section{The nature of religion}

Readers of this journal are unlikely to need a long discourse on the nature of religion, even if the phrase is less common than its equivalent - 'the nature of science'. As is well known, it is rather difficult to answer the question 'What is a religion?' in a way that works for all religions. Nevertheless, the following, derived from Smart (1989) and Hinnells (1991), are generally held to be characteristic of most religions:

- Religions have a practical and ritual dimension that encompasses such elements as worship, preaching, prayer, yoga, meditation and other approaches to stilling the self.

- The experiential and emotional dimension of religions has at one pole the rare visions given to some of the crucial figures in a religion's history, such as that of Arjuna in the Bhagavad Gita and the revelation to Moses at the burning bush in Exodus. At the other pole are the experiences and emotions of many religious adherents, whether a once-in-a-lifetime apprehension of the transcendent or a more frequent feeling of the presence of God either in corporate worship or in contemplative practices.

- All religions hand down, whether orally or in writing, vital stories that comprise the narrative or mythic dimension, for example the story of the Babylonian exile in the Judaeo-Christian scriptures and the roles played by Ezra and Nehemiah. For some religious adherents such stories are believed literally, for others they are understood more symbolically.

- The doctrinal and philosophical dimension. For instance, the early Christian church came to its understanding of the doctrine of the Trinity by combining the central truth of the Jewish religion - that there is but one God - with its understanding of the life and teaching of Jesus Christ and the working of the Holy Spirit.

- The ethical and legal dimension regulates how believers act. So, Sunni Islam has its Five Pillars, Judaism has its 613 mitzvot in the Torah and Buddhism its Five Precepts.

- The social and institutional dimension, for example, the Sangha in Buddhism, the umma' in Islam, the Church in Christianity and pilgrimage in many religions.

- Finally, there is the material dimension, for example, synagogues, temples, churches, Eastern Orthodox icons, Hindu Murtis, prayer beads and Jewish Yadayim (Torah pointers).

In England, there is a long history of attempts to improve curricula for RE by seeking to look afresh at the content of the RE curriculum, the criteria by which such content is identified and sequenced and at how RE is taught. A recent report, Big Ideas for Religious Education

Stones, A., Pearce, J., Reiss, M. J. \& Mujtaba, T. (2020) Students' perceptions of religion and science, and how they relate: The effects of a classroom intervention. Religious Education. DOI: 
(Wintersgill et al. 2017), identified the following seven key issues that the authors felt RE should help students address:

- The origin, destiny and purpose of the universe and everything in it

- The place of human beings in the universe

- Personal spirituality

- Expressing our deepest thoughts and feelings

- Moral issues and how to resolve them.

- The nature of religion

- The power and influence of religions: religious conflict.

It is notable that in addition to one of these (the sixth) that specifically addresses 'The nature of religion', there are two (the first two) that require students to have a reasonable understanding of the scope of both science and religion. Some of the latest recommendations for RE, based on a report conducted by the Commission on Religious Education (2018), identify the need for the subject to reflect, and include the academic study of, non-religious and religious worldviews, and the reasons for people holding combinations of these. This explicit focus for RE is in reference to the recent identification of the diverse beliefs and practices of the 'nones', a growing group of young people in Britain, Australia and the USA, who poll as not religious but often not atheist either (YouGov 2013; Woodhead 2014; Singleton 2015) and for whom questions of epistemology and related complementarity may seem pertinent.

\section{Student understanding of religion and science}

For the majority of published studies on student understandings of religion and science, 'religion' refers to one or more of the Abrahamic religions. Most of the empirical studies use qualitative rather than quantitative or mixed methods. Most studies focus on the origins and history of life and the universe. Given the on-going and heated debates surrounding the teaching of evolution and creationism/intelligent design in schools - long held in the USA and now prevalent in many other countries including England (Deniz and Borgerding 2018) it is perhaps unsurprising that much research is undertaken in these areas.

In the public domain, debates concerning religion and science are often framed in terms of a conflict with each of us expected to choose whether we trust in science or believe in a particular faith tradition. It is noteworthy that the literature is mostly focused on perceptions of the relationship between religion and science, rather than on perceptions of religion and science in their own right. Yasri, Arthur, Smith and Mancy (2013) provide a review of taxonomies and identify a number of important conceptual (Polkinghorne 1986; Barbour 1990; Haught 1995; Nord 1999; Alexander 2007) and empirical (Hokayem and BouJaoude 2008; Shipman et al. 2002; Taber et al. 2011; Yasri and Mancy 2014) frameworks. All in all, a taxonomy of seven kinds of understandings of the relationship between religion and science emerge from Yasri et al.'s (2013) analysis: 


- $\quad$ Conflict: science trumps religion
- $\quad$ Conflict: religion trumps science
- $\quad$ Contrast: different questions
- $\quad$ Contrast: different methods
- $\quad$ Coalescence
- Complementary.

However, what Yasri et al. (2013) appear not to have included in their taxonomy is the large number of learners who are undecided or who simply do not know, either because they have not given the relationship between religion and science much thought or because they consider such matters as the origin of the universe to be beyond human comprehension (Billingsley et al. 2012).

\section{Methodology}

The focus of this article is on how RE can help students develop their understandings of issues to do with the relationship(s) between religion and science. At the same time, this raises questions about what we might expect science lessons to contribute to such understandings. In England there is strong agreement amongst science educators and teachers that it is at the least probably unwise, and perhaps inappropriate, for science teachers to start engaging in discussions with students about religious matters, including the validity and interpretation of scripture; such discussions are best left to RE teachers (DCSF 2007).

However, students may also raise issues to do with the relationship between religion and science that are appropriate for discussion in the science classroom. For example, a creationist student might raise the objection that science makes unwarranted assumptions about the constancy over time of radioactive decay rates that are used to date fossils and determine the age of the Earth, or might maintain that the theory of evolution contradicts the Second Law of Thermodynamics (Reiss 2008b).

Students may also raise issues that lie part way between scriptural hermeneutics and mainstream science. For instance, what should a science teacher do with questions about whether there is life after death? Some maintain that such a belief is contradicted by science (e.g., Atkins 2011). However, others maintain that this question lies outside of science - as, for example, do questions about aesthetics and morality. Perhaps a science teacher might want students to think about, to help them better understand the nature of science, whether or not such questions sit within the domain of science, and the reasons for this.

We adopted an interpretivist research design and sought to obtain Year 9/10 students' (aged 13-15) perspectives on the relationship(s) between religion and science, and determine the effects of lessons specifically focused on enabling and encouraging students to explore links between religion and science. Students took part in semi-structured group interviews before and after the intervention of six RE and six science lessons that were taught during the same period of time over the course of a school year. Students were asked:

1. What do you think of science?

2. What do you think of religion?

3. Do you believe that science and religion have anything in common? 
4. To what extent do you agree with this statement: 'People who accept evolution do not believe in God'?

5. Would you support an alternative viewpoint being discussed/taught alongside scientific theories in the Science classroom, e.g. creationism or ideas and beliefs about life after death?

During the post-intervention interview, before being asked questions four and five, students were explicitly asked to be mindful of their learning from the intervention lessons. Each interview question was addressed to each student in turn. This has the advantage of allowing comparison of student responses at the level of individual students - including comparing their responses before and after the intervention, the particular focus of our analysis. The same person (the fourth author, an experienced interviewer) conducted all the interviews and every effort was made to ensure that students felt comfortable, so that they were able to speak freely and express their viewpoints.

\section{The intervention}

The intervention consisted of six RE and six biology lessons ${ }^{1}$, taught by students' usual teachers. In advance of the lessons, the teachers attended distance (e.g. Skype or FaceTime) professional development sessions about the purpose and content of the lessons.

The RE lessons were intended to enable the Year 9/10 students to consider the relationship(s) between religion and science in a critical and reflective manner. They were characterized by a variety of pedagogical strategies from written 'dialogues' to discussions and debates. The intention was to allow different levels of social engagement that would include all students in the investigation of how religion and science relate. The role of criteria in the evaluation of knowledge claims was given considerable emphasis as some of the lessons sought to provoke an awareness of the connections between different types of criteria, knowledge frameworks and authority. Rather than providing explicit teaching about epistemology, our approach was to create lessons which immersed students in the sorts of debates that raise epistemological issues.

\section{RE lesson one: Religion and Science: Two windows?}

Drawing on Freeman Dyson's acceptance speech for the 2000 Templeton

Prize, in which he identified the metaphor of religion and science as two windows through which we can understand the world, the first lesson in the sequence introduces the possibility of differences and similarities concerning knowledge between religion and science. Students evaluate the usefulness of the metaphor of the window through discussions. They then create, share and discuss their own diagrams to represent their definitions of religion and science as domains of knowledge and include their views of the relationship(s) between them.

\section{RE lesson two: Can we survive death?}

The stimulus for the lesson is Pojman's (2001) thought experiment of a successful brain transplant. Students investigate, through paired and group discussions, the (religious and scientific) criteria we might use to define

\footnotetext{
${ }^{1}$ Information about the project on which this article was based, '[removed for anonymised review]', including the lesson plans and resources used in this research, can be found at [removed for anonymised review]. Stones, A., Pearce, J., Reiss, M. J. \& Mujtaba, T. (2020) Students' perceptions of religion and science, and 8 how they relate: The effects of a classroom intervention. Religious Education. DOI: 
personhood, death and survival, in order to respond to the question in the lesson's title.

\section{RE lesson three: Soul survivor}

Students are presented with a variety of arguments for and against the existence of the soul from different religious and non-religious perspectives. The focus of this lesson is a philosophical one in which students are asked to establish and evaluate the different sorts of criteria regarding the soul to gain insights into the various methods and discourses employed.

\section{RE lesson four: Ethics of cloning}

In this lesson, students begin with a discussion of how we might decide when life begins and ends. Students go on to interpret An Experiment on a Bird in the Air Pump (1768), by Joseph Wright of Derby (Figure 1), in which a scientist demonstrates the use of a vacuum through the possible death of a bird. Thought and speech bubbles, or an enactment of the scene, allow students to consider the variety of attitudes to this experiment and the ethical questions that this scientific progress presents. They then reflect on the case of Dolly the sheep, the issue of 'unused' embryos in human stem cell treatment, as well as a selection of religious and non-religious statements regarding medical ethics and the sanctity of life. Finally, students are asked to produce an image or diagram in the style of Wright's painting to show the diverse attitudes to recent scientific developments.

\section{RE lesson five: Seeing is believing}

This lesson asks students to reflect on their understandings and experiences of knowing and believing, the similarities and differences between these, and relevant sources of authority. Through discussions, enactments of their ideas and conversations on paper, they explore their own and other students' views of authority according to religious doctrine and scientific theories. Using the optical illusion of the duck-rabbit as a metaphor for religious belief and nonreligious knowledge, students end by analyzing the possibility of holding apparently contrasting positions simultaneously.

\section{RE lesson six: What is the relationship between science and religion? Does it matter?}

This lesson acts as a plenary to the sequence. Students are reacquainted with contrasting ideas, statements and texts from previous lessons and asked to create a representation of their understanding of the relationship between religion and science (and their own process in reaching their understanding). They do this in groups and are asked to include the challenges and advantages of sharing their perceptions with their peers. This was considered central to the intervention so as not to coerce students into comfortable compromises but encourage them to engage with a diversity of perceptions through their peers and other stimuli. Finally, students are asked their views of the relevance of the study of the relationship between religion and science.

The biology lessons are described in Mujtaba et al. (2017). 
The intervention was conducted with six schools and we asked schools to involve Year 9 and/or Year 10 classes. We obtained interview data from a total of 40 students, including at least six students from each school. All students have been given pseudonyms.

\section{Data analysis}

In our analysis of data, we were interested in students' perceptions of religion and science, and their relationship(s), before the intervention and in the effects, if any, of the intervention on these perceptions. We recognize, of course, that other factors in addition to the intervention lessons might influence students' perceptions. Codes were established to indicate whether students' views changed or not, and the nature of and reasons for these changes (or lack thereof) in terms of the perceived relationship(s) between religion and science. The codes are also discussed below in terms of their relation to Yasri et al.'s (2013) categorization and Preston and Epley's (2009) identification of 'explanatory space', as explained below.

\section{Findings}

Some students did not change their views

Sixteen of the 40 students either stated that their views did not change or gave answers that indicated no change. By far the most common reason for this was that both before and after the lessons the students felt that religion and science were incompatible. For example:

I don't think they really have a lot in common because religion is like all spiritual and stuff and it's all about belief and science is all about like matter and things which are actually there.

(Ben, after the intervention)

They have some relevance to each other but they're never going to really be able to mix.

(Jess, before the intervention)

Because they're both two opposite ends of the spectrum.

(Jess, after the intervention)

The perspective that religion and science 'have nothing in common' and inevitably disagree is in line with Preston and Epley's (2009) assertion that these distinct 'systems' are vying for the same 'explanatory space'. Some students whose views did not change did not consider there to be a conflict between religion and science. For example:

Yes, they're both theories about how the universe was created and stuff like that. (Rashid, after the intervention)

\section{Most students changed their views}

Twenty one of the students changed their views about the relationship between religion and science. Eighteen of these moved from seeing the relationship as one of conflict or 
incompatibility to the view that the relationship was not incompatible. The most common position among these 18 was to hold, after the lessons, that religion and science answer the same questions in different ways. For example:

It's a bit of a thing and you have to know it. I think that they don't really go well together because, for example, the theory of evolution right, yeah? If let's say the Bible sort of like - how did the Bible see if we get there? They say that one animal evolved from another, but the thing is how did that animal get there in the first place? I think that religion made that. Then like, okay, if they did evolve then how did one turn into another because like - I don't know but ... Yeah, but how did that happen? (Alison, before the intervention)

I think that they - yes, they have opposed style but then they have different things about them and they have different beliefs about what the world is and what it's about.

(Alison, after the intervention)

Another group of students moved from a perceived conflict to a compatibility which could reflect what Yasri et al. (2004) refer to as 'coalescence'. For example:

They have some relevance to each other but they're never going to really be able to mix.

(Jess, before the intervention)

Yes, I think they can exist together but you can believe one thing because if you believe something and you know something, that doesn't mean they can't necessarily agree, but evolution offers some explanations that religion can't but religion can also offer something else that perhaps biology won't be able to offer to you. (Jess, after the intervention)

Three of the students moved from seeing the relationship between religion and science as compatible to conflictual. For example:

... it only changed my view to make me a bit more biased towards my religion to be honest. I understand that science does stuff and it affects you and stuff but I feel more biased towards my religion, that my religion is the right way.

(Amina, after the intervention)

\section{Changes in views that do not concern the relationship between religion and science}

Twenty eight of the students indicated changes in their views that were not directly to do with the relationship between religion and science. These are discussed here because they are pertinent to our question concerning implications for RE.

Thirteen students expressed their appreciation of the opportunity to discuss and reflect on the natures of religion and science, and their relationship(s). Some students mentioned that they did not usually get this opportunity in RE, and they considered our approach effective. For example: 
I feel the lessons have helped a bit because obviously alongside you can obviously, they haven't changed my views but I now can appreciate how people feel, that I'm never going to judge them or say they're wrong or something but it hasn't changed my view.

(Rachel, after the intervention)

Some students indicated that they felt greater empathy towards others, or at least were less antagonistic towards others' views. For example:

... but after those interviews and the lessons, I started to think that maybe there is room for science and I can respect people's opinions in science as long as they can respect mine but it's my religion, I won't be - I won't be so protective about it and I won't be so against you but rather I'd be intrigued to know what your opinion is on my faith and my religion ...

(Alison, after the intervention)

However, for some students an increase in empathy led to the avoidance of critical engagement with others' views. Fred's comments indicate that students can reduce a worldview to an 'opinion', which might be understood in relativist and uncritical terms:

I find that my opinion is my opinion and I will not go against someone else's because it's their own personal opinion.

(Fred, after the intervention)

Six of the students after the lessons talked about how their view had moved from seeing religion as something that was out of date to one where they could see a positive side to religion in terms of its contribution to society, even for those who don't have religious beliefs.

\section{Misunderstandings about how the knowledge claims of religion or science}

In response to several of the interview questions, fourteen of the students, either before or after the lessons, used language in ways that indicated misunderstandings about how religion or science function in respect to their knowledge claims. For example:

I think they can both balance each other out and I've understood respect of religion more than I had. I still think science is definitely a lot stronger because it's fact, whereas religion is just going on theory more ... and science does have a lot more answers and religion just goes on the belief aspect, so although I understand it a bit more, I still think science is better and it's going to answer more questions.

(Jess, after the intervention)

I think that it [alternative viewpoints to scientific theories] shouldn't be taught together in a science classroom because science is all about evidence and backing things up with evidence but religion is more of a belief and a feeling, rather than solid proof.

(Mary, after the intervention) 
Most of these uses of language suggested that religion was viewed by these students as making empirical claims open to testing through the methods of the natural sciences. Sometimes, though, students manifested misunderstandings as to how science operates. For example:

I think that because I'm religious, I believe that God created things and the Big Bang - learning about the Big Bang theory alongside it in class, it showed me that science is also a religion in a way because it's a belief of how things are created.

(Mary, after the intervention)

\section{Discussion}

A Durkheimian (Durkheim 1912/1915) view acknowledges the lack of distinction between religion and science, since science was historically understood within the socio-cultural framework. Indeed, many sacred texts containing, for example, explanations of creation are illustrations of this unity. However humans developed their awareness of religion and science and began to practise them, both have played and continue to play enormous roles in the lives of humans around the globe. Yet many students end their compulsory education with no more than the poorest understanding of how each 'discipline' (we acknowledge the limitations in describing religion as a discipline) operates and builds knowledge. In addition, it is difficult to imagine two disciplines where there is a greater range of presumptions as to how they interrelate.

This research was undertaken with the specific aim of seeing whether a rather modest teaching intervention - just six RE lessons (along with six science lessons that had a different, though related aim) and quite sparse teacher professional development - might make a difference to the views and understandings of the students who were taught these lessons. Enabling students to consider how "belief systems often provide different explanations for the same phenomena" and thus compete for "explanatory space" (Preston and Epley 2009, 238) is part and parcel of what many specialist school teachers of religion would see as one of their aims. RE teachers are well-placed to enable young people to grapple in a critical manner with questions such as whether religion and science are competing for the same explanatory space, and what kinds of criteria can and should be used to evaluate explanations that each discipline provides.

Our data show that, not infrequently, students' perceptions of the relationship(s) between religion and science demonstrate that "gut reactions" (Preston and Epley 2009, 240) and "pragmatic" approaches (Stolberg 2007) persist. However, our data analysis also showed that the majority of students changed their views as a result of the intervention and the opportunity to reflect on the relationship(s) between religion and science. Following Yasri and Mancy (2014), and the indications from our analysis that many students, subsequent to the lessons, manifested improved understandings of the different ways that religion and science arrive at conclusions about knowledge, RE teachers might consider presenting students with at least a simplified taxonomy of the possible relationship(s) between religion and science to students. This should help students in engaging critically with this issue and reflectiong on how their own positions compare to those of others.

We found that many students latched onto scientific and religious understandings of evolution and creation as the totemic instances of how religion and science relate, even

Stones, A., Pearce, J., Reiss, M. J. \& Mujtaba, T. (2020) Students' perceptions of religion and science, and 
though the RE lessons were designed to explore areas beyond the origins of life and the universe. We suggest that teachers of RE try, from an early age of their students, to get students to consider how religion and science relate in other areas that raise different issues for students and draw the focus away from a presumption that there is simply a binary choice to be made. Issues of medical ethics, robots, sustainability and the value of wildlife, for example, provoke broader opportunities for students to explore issues to do with the nature and value of life, and the question of what it is to be human, not to mention the need to scrutinize the urge for 'progress'.

Despite official guidance that encourages science teachers in England to explore the scientific evidence in respect of creationism (if they feel comfortable so doing) when the issue arises in science lessons (DCSF 2007), creationism is more likely to be discussed in England in RE lessons. If we recognize the importance of students understanding the epistemological characteristics of creationist positions, then the responsibility lies with RE teachers to facilitate such understanding and extend it to other instances of interactions between religion and science. At the same time, teachers have a duty of care towards creationist students, who must be treated sensitively, as should be students who are atheists or agnostics in faith schools (Reiss 2019).

In conclusion, this study shows that while many 13-15 year-old students come to their RE lessons with a poor understanding of the nature of religion, the nature of science and how religion and science inter-relate, a fairly modest teaching intervention can engage students and succeed in providing many of them with a much richer set of understandings.

\section{Acknowledgements}

We are extremely grateful to Templeton World Charity Foundation for funding and to the teachers and students who participated in the research reported here.

\section{References}

Alexander, D. R. 2007. Models for relating science and religion. https://faradayinstitute.org/resources/Faraday\%20Papers/Faraday\%20Paper\%203\%20Alexander_EN.pdf

Atkins, P. 2011. On being: A scientist's exploration of the great questions of existence. Oxford: Oxford University Press.

Barbour, I. G. 1990. Religion in an age of science. London: SCM Press.

Billingsley, B., K. S. Taber, F. Riga, and H. Newdick. 2012. "Secondary school students' epistemic insight into the relationships between science and religion - a preliminary enquiry." Research in Science Education, 43 (4): 1715-1732.

Commission on Religious Education. 2018. Religion and worldviews: The way forward. London: Religious Education Council of England \& Wales. Available at https://www.commissiononre.org.uk/wp-content/uploads/2018/09/Final-Report-of-theCommission-on-RE.pdf.

DCSF. 2007. Guidance on creationism and intelligent design. London: DCSF. Available from:

http://webarchive.nationalarchives.gov.uk/20071204131026/http://www.teachernet.gov.uk /docbank/index.cfm?id=11890.

Stones, A., Pearce, J., Reiss, M. J. \& Mujtaba, T. (2020) Students' perceptions of religion and science, and 14 how they relate: The effects of a classroom intervention. Religious Education. DOI:

$10.1080 / 01416200.2019 .1635434$. 
Deniz, H., and L. A. Borgerding, eds. 2018. Evolution education around the globe. Dordrecht: Springer.

Durkheim, E. 1912/1915. The elementary forms of the religious life. London: George Allen \& Unwin.

Haught, J. F. 1995. Science and religion: From conflict to conversation. New York: Paulist Press.

Hinnells, J. R. 1991. A handbook of living religions. London: Penguin Books.

Hokayem, H., and S. BouJaoude. 2008. "College students' perceptions of the theory of evolution." Journal of Research in Science Teaching, 45 (4): 395-419.

Kuhn, T. S. 1970. The structure of scientific revolutions, $2^{\text {nd }}$ edn. Chicago: University of Chicago Press.

Lakatos, I. 1978. The methodology of scientific research programmes. Cambridge: Cambridge University Press.

Merton, R. K. 1973. The sociology of science: Theoretical and empirical investigations. Chicago: University of Chicago Press.

Mujtaba, T., M. J. Reiss, and A. Stones. 2017. "Epistemic insight: Teaching about science and RE in secondary schools." School Science Review, 99 (367): 67-75.

Nord, W. A. 1999. "Science, religion, and education.” Phi Delta Kappan, 81 (1): 28-33.

Pearce, J., A. Stones, M. J. Reiss, and T. Mujtaba. 2019. "'Science is purely about the truth so I don't think you could compare it to non-truth versus the truth.' Students' perceptions of religion and science, and the relationship(s) between them: Religious Education and the need for epistemic literacy." British Journal of Religious Education. doi: 10.1080/01416200.2019.1635434.

Polkinghorne, J. C. 1986. One world: The interaction of science and theology. London: SPCK.

Popper, K. R. 1934/1972. The logic of scientific discovery. London: Hutchinson.

Preston, J., and N. Epley. 2005. "The explanatory value of meaningful beliefs." Psychological Science 16: 826-832.

Reiss, M. J. 2008a. "Should science educators deal with the science/religion issue?" Studies in Science Education, 44: 157-186.

Reiss, M. J. 2008b. "Teaching evolution in a creationist environment: an approach based on worldviews, not misconceptions." School Science Review, 90 (331): 49-56.

Reiss, M. J. 2019. "Evolution education: treating evolution as a sensitive rather than a controversial issue." Ethics and Education, 14 (3): 351-366.

Shipman, H. L., N. W. Brickhouse, Z. Dagher, and W. J. Letts. 2002. "Changes in student views of religion and science in a college astronomy course." Science Education, 86 (4): 526-547.

Singleton, A. 2015. "Are religious 'nones' secular? The case of the nones in Australia." Journal of Beliefs \& Values, 36 (2): 239-243.

Smart, N. 1989. The world's religions: Old traditions and modern transformations. Cambridge: Cambridge University Press.

Stolberg, T. L. 2007. "The religio-scientific frameworks of pre-service primary teachers: An analysis of their influence on their teaching of science." International Journal of Science Education, 29 (7): 909-930.

Taber, K. S., B. Billingsley, F. Riga, and H. Newdick. 2011. 'Secondary students' responses to perceptions of the relationship between science and religion: Stances identified from an interview study." Science Education, 95 (6): 1000-1025.

Wintersgill, B., A. Brine, D. Cush, D. Francis, R. Freathy, F. Henchley, J. Holt, J. Stern, J. Orchard, M. J. Reiss, L. Rudge, J. Schmack, and K. Walshe. 2017. Big ideas for

Stones, A., Pearce, J., Reiss, M. J. \& Mujtaba, T. (2020) Students' perceptions of religion and science, and 15 how they relate: The effects of a classroom intervention. Religious Education. DOI:

$10.1080 / 01416200.2019 .1635434$. 
Religious Education. Exeter: University of Exeter. Available at http://socialsciences.exeter.ac.uk/media/universityofexeter/collegeofsocialsciencesandint ernationalstudies/education/research/groupsandnetworks/reandspiritualitynetwork/Big_Id eas for RE E-Book.pdf.

Woodhead, L. 2014. Launch series: The 'fuzzy nones'. http://faithdebates.org.uk/wpcontent/uploads/2014/04/Linda-Woodhead-the-fuzzy-nones_pdf.

Yasri, P., S. Arthur, M. Smith, and R. Mancy. 2013. "Relating science and religion: An ontology of taxonomies and development of a research tool for identifying views." Science \& Education 22 (10): 2679-2707.

Yasri, P., and R. Mancy. 2014. "Understanding student approaches to learning evolution in the context of their perceptions of the relationship between science and religion." International Journal of Science Education 36 (1): 24-45.

YouGov.2013. YouGov / University of Lancaster survey results. http://cdn.yougov.com/cumulus_uploads/document/mm7go89rhi/YouGovUniversity\%20of\%20Lancaster-Survey-Results-Faith-Matters-130130.pdf. 
Figure 1: Joseph Wright of Derby's An Experiment on a Bird in the Air Pump. This image was used to help students consider the ethical implications of cloning and stem cell research. Taken from

https://upload.wikimedia.org/wikipedia/commons/c/c4/An_Experiment on a Bird in the A ir Pump.jpg.

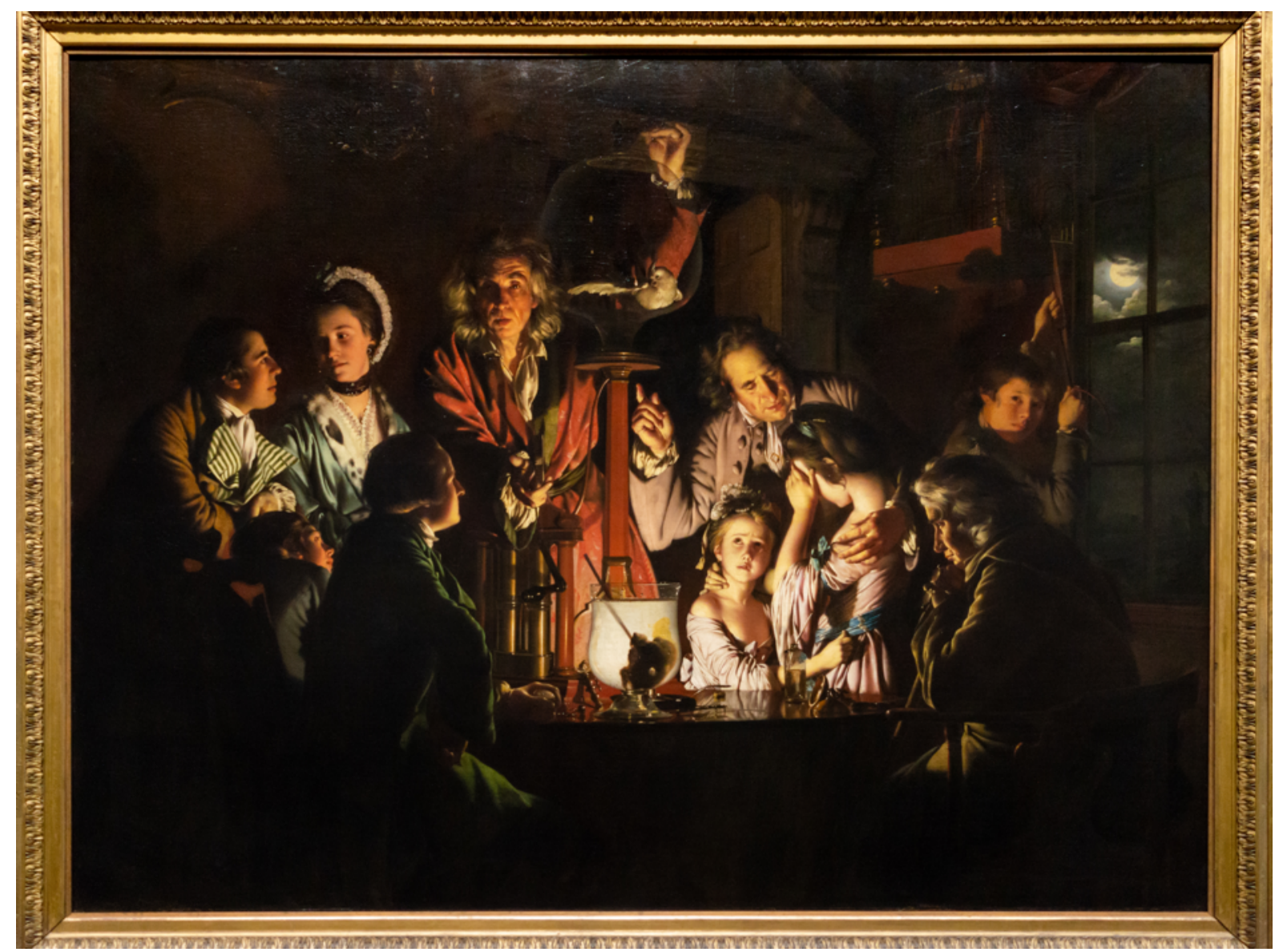




\section{Notes on Contributors}

All four authors work at UCL Institute of Education, University College London. Alexis Stones is a Senior Teaching Fellow, Jo Pearce is a Principal Teaching Fellow, Michael J. Reiss is Professor of Science Education, Tamjid Mujtaba is a Senior Research Officer. Correspondence concerning this article should be addressed to the corresponding author: Alexis Stones, UCL Institute of Education, University College London, 20 Bedford Way, London WC1H 0AL, UK. E-mail: a.stones@ucl.ac.uk. 